\title{
PENGARUH KELAS IBU HAMIL TERHADAP PENGETAHUAN DAN SIKAP IBU HAMIL TENTANG PERSIAPAN PERSALINAN
}

\author{
Yadul Ulya $^{1)}$, Susilia Idyawati ${ }^{1)}$ \\ Email : yadul.ulya90@yahoo.com \\ ${ }^{1)}$ Program Studi Kebidanan Jenjang D.3, STIKES Yarsi Mataram
}

\begin{abstract}
ABSTRAK
Tingginya AKI dan AKB antara lain disebabkan oleh rendahnya pengetahuan ibu dalam perawatan kesehatan ibu. Program yang dicanangkan Indonesia untuk meningkatkan pengetahuan ibu hamil salah satunya adalah kelas ibu hamil, yang diharapkan dapat meningkatkan pengetahuan dan keterampilan ibu hamil mengenai kehamilan, persalinan, perawatan nifas dan perawatan bayi baru lahir. Penelitian ini bertujuan untuk pengaruh kelas ibu hamil terhadap pengetahuan dan sikap ibu hamil tentang persiapan persalinan. Penelitian ini bersifat eksperimen dengan desain One-Group Pretest-Postest. Populasi dalam penelitian ini adalah ibu hamil pada bulan April 2018 di Desa Sesela Wilayah Kerja Puskesmas Gunung Sari Kabupaten Lombok Barat yang berjumlah 30 ibu hamil. Data diperoleh melalui kuesioner. Analisis menggunakan Uji paired t-test. Penelitian menunjukkan nilai rerata pengetahuan berdasarkan pelaksanaan kelas ibu hamil pre test adalah 39,83 dan setelah pelaksanaan kelas ibu hamil 72,33 (post test), adanya perbedaan yang bermakna $(\mathrm{p}=0,000<\alpha 0,05)$. Sedangkan nilai rerata sikap berdasarkan kelas ibu hamil pretest adalah 50,53 dan setelah pelaksanaan kelas ibu hamil 72,03, adanya perbedaan yang bermakna $(\mathrm{p}=0,000<\alpha 0,05)$. Ada pengaruh kelas ibu hamil terhadap pengetahuan dan sikap ibu hamil tentang persiapan persalinan di Desa Sesela Wilayah Kerja Puskesmas Gunung Sari Kabupaten Lombok Barat.
\end{abstract}

Kata Kunci: Kelas ibu hamil, pengetahuan, persiapan persalinan, sikap

\begin{abstract}
The high AKI and AKB are caused, among other things, by the low mother tongue in maternal health care and the introduction of obstetric and neonatal danger signs, a decision that will produce inappropriate decisions. One effort to be able to provide sufficient knowledge for pregnant women and families through the class of pregnant women. Classes for pregnant women are community empowerment activities through group learning facilities about the health of pregnant women using KIA books. This study aims to increase the knowledge of pregnant women on the knowledge and attitudes of pregnant women about labor preparation. Study was experimental with the design of the Pretest-Posttest One-Group. The population in this study were pregnant women in April 2018 in the Sesela Village Working Area of Gunung Sari Public Health Center West Lombok Regency who worked 30 pregnant women. Data obtained through questionnaires. Analysis using paired t-test.The study showed that the average value of knowledge based on the implementation of pre-test pregnant women was 39.83 and after the implementation of 72.33 (post-test) classes, there were clear differences $(p=0.000<\alpha 0.05)$. The average value of attitudes based on the pretest pregnant class is 50.53 and after the implementation of 72.03 pregnant women, a significant value $(p=0.000<\alpha 0.05)$.Pregnant women about the knowledge and attitudes of pregnant women about childbirth preparation in Sesela Village, Gunung Sari Health Center, West Lombok District.
\end{abstract}

Keywords: Attitude, Class of pregnant women, knowledge, preparation for labor 


\section{A. LATAR BELAKANG}

Pembangunan kesehatan di Indonesia saat ini diprioritaskan pada program peningkatan derajat kesehatan ibu dan anak, hal ini dikarenakan ibu dan anak merupakan kelompok yang paling rentan kesehatanya[1]. Indikator derajat kesehatan masyarakat berhubungan erat dengan Angka Kematian Ibu (AKI). Angka kematian ibu dan kematian anak di Indonesia relatif tinggi dibandingkan negara-negara ASEAN lainnya. Survei Demografi Kesehatan Indonesia (SDKI), Angka Kematian Ibu (AKI) yang berkaitan dengan kehamilan, persalinan, dan nifas sebesar 359/100.000 kelahiran hidup. Rata-rata kematian ini jauh meningkat dibanding hasil SDKI tahun 2007 yang mencapai 228/100.000 kelahiran hidup. Maka peningkatan AKI tersebut perlu ditindak lanjuti sehingga dapat menurunkan AKI di Indonesia[2].

Tingginya AKI dan AKB antara lain disebabkan karena ketidakberdayaan seorang ibu dalam memutuskan untuk mendapatkan pertolongan medis apabila terjadi permasalahan pada kehamilan dan bayinya. Hal ini antara lain disebabkan oleh rendahnya pengetahuan ibu dalam perawatan kesehatan ibu serta pengenalan tanda-tanda bahaya obstetri dan neonatal, sehingga akan menghambat suatu keputusan yang harus diambil[3].

Upaya penurunan kematian ibu dan bayi, dapat dilakukan dengan peningkatan cakupan dan kualitas pelayanan kesehatan ibu dan anak. Salah satu upaya yang dilakukan adalah memberdayakan keluarga dan masyarakat untuk meningkatkan pengetahuan dan kemandirian dengan membuat perencanaan persalinan. Diperlukan peran tenaga kesehatan untuk memberikan pendidikan kesehatan kepada ibu hamil untuk dapat menjaga kehamilannya serta mempersiapkan persalinan sehingga dapat mengantisipasi secara dini kegawatdaruratan maternal neonatal yang mungkin terjadi[3].

Ibu hamil penting sekali mempunyai pengetahuan tentang persalinan. Dalam hal ini para bidan sebagai ujung tombak pelayanan kesehatan di masyarakat diharapkan untuk berupaya memberikan informasi yang selengkap-lengkapnya kepada ibu hamil. Dalam menghadapi persalinan tidak lepas dari sikap ibu hamil tentang persalinan. Ibu yang mempunyai sikap yang baik tentang persalinan akan menjaga kehamilannya dan menyiapkan apa saja yang dibutuhkan untuk menghadapi persalinan. Tentunya hal ini terkait dengan sejauh mana pengetahuannya tentang persalinan yang diharapkan dapat berjalan normal dan tidak ada kendala[1].

Program yang dicanangkan Indonesia untuk meningkatkan pengetahuan ibu hamil salah satunya adalah kelas ibu hamil. Kelas ibu hamil merupakan sarana untuk belajar bersama tentang kesehatan bagi ibu hamil, dalam bentuk tatap muka dalam kelompok yang diikuti oleh ibu hamil dengan umur kehamilan antara 20 minggu s/d 32 minggu dengan jumlah peserta maksimal 10 orang[3].

Dengan mengikuti program kelas ibu hamil diharapkan ibu hamil dapat meningkatkan pengetahuan dan keterampilan ibu-ibu mengenai kehamilan, persalinan, perawatan nifas dan perawatan bayi baru lahir, mitos, penyakit menular dan akte kelahiran. Kelas ibu hamil dapat menjadikan ibu hamil terhindar dari masalah-masalah kesehatan pada saat masa kehamilan sampai nifas yang dapat menimbulkan risiko pada ibu dan janin serta bayinya kelak. Hasil akhir yang diharapkan dari kegiatan ini adalah setiap ibu hamil bisa melewati masa kehamilan, persalinan, dan masa nifas dengan selamat yang akan berdampak pada penurunan Angka Kematian Ibu (AKI)[3].

Pada tahun 2010, Kepala Dinas Kesehatan Lombok Barat membuat kebijakan bahwa semua ibu hamil wajib mengikuti kegiatan kelas ibu hamil. Kebijakan ini didasari oleh masih adanya kasus-kasus komplikasi maternal yang terlambat dirujuk ke fasilitas kesehatan, masih rendahnyanya persalinan di tenaga kesehatan dan tingginya kasus kematian ibu. Salah satu hasil yang terlihat dari pelaksanaan kelas ibu hamil di wilayah Lombok Barat adalah turunnya angka kematian ibu, dari 131/100.000 kh pada tahun 
2010 menjadi 74/100.000 kh pada tahun 20111.

Menurut penelitian sebelumnya menunujukkan persiapan persalinan adalah usaha ibu hamil untuk menghadapi kelahiran bayi yang meliputi persiapan fisik, mental (psikologis) dan materi yang cukup agar kelahiran anak berjalan dengan lancar, menghasilkan ibu dan anak yang sehat[4].

Penerapan kelas ibu hamil diharapkan dapat meningkatkan aksesibitas ibu hamil terhadap pelayanan kesehatan ibu dan anak yang berkualitas sehingga dapat menjadi salah satu upaya dalam penurunan AKI dan AKB. Pengaruh yang terjadi dari pemberian materi kelas ibu hamil yang disampaikan secara komprehensif dan berkesinambungan diharapkan terjadi peningkatan pengetahuan dan sikap ibu hamil dalam persiapan persalinan[3].

Pengetahuan ibu hamil tentang kelas ibu hamil yang meliputi pengertian, tujuan, manfaat dan pelaksanaan serta materi yang diajarkan dalam kelas ibu hamil akan memperbesar kemungkinan seorang ibu hamil mengikuti kelas ibu hamil di wilayahnya. Berdasarkan penelitian Historyati menyatakan bahwa pengetahuan ibu tentang manfaat dari kelas ibu hamil akan membuat seorang ibu hamil mencari informasi dan pelayanan kesehatan untuk menjaga kesehatan dirinya dan kehamilannya[5].

Berdasarkan hasil wawancara awal dengan 8 ibu hamil yang datang untuk melaksanakan kelas ibu hamil pada hari pertama di Desa Sesela Kecamatan Gunung Sari Kabupaten Lombok Barat, di dapatkan 6 ibu hamil belum mengetahui tentang persiapan persalinan, 2 ibu mengatakan sudah mengetahui tetapi belum memahami tentang persiapan persalinan. Penelitian ini bertujuan untuk mengetahui pengaruh kelas ibu hamil terhadap pengetahuan dan sikap ibu hamil tentang persiapan persalinan.

\section{B. METODE PENELITIAN}

Penelitian ini bersifat eksperimen dengan desain One-Group Pretest-Postest. Sampel dalam penelitian ini adalah ibu hamil pada bulan
April 2018 di Desa Sesela Kecamatan Gunung Sari Kabupaten Lombok Baratyang berjumlah 30 ibu hamil. Data diperoleh melalui wawancara langsung kepada responden dengan berpedoman pada kuesioner. Analisis dilakukan secara deskriptif dengan menggunakan tabel distribusi frekuensi tiap variabel yang digunakan dalam penelitian baik variabel dependen maupun variabel independen, dan untuk mengetahui Pengaruh Kelas Ibu Hamil Terhadap Pengetahuan dan Sikap Ibu Hamil Tentang Persiapan Persalinan di Desa Sesela Kecamatan Gunung Sari Kabupaten Lombok Barat, digunakan uji $\mathrm{t}$ berpasangan (paired t-test), dengan bantuan SPSS, versi 23.

\section{HASIL DAN PEMBAHASAN}

\section{Analisis Univariat}

Tabel 1 Kategori Pengetahuan Pre Test dan Post Test Tentang Persiapan Persalinan

\begin{tabular}{|c|c|c|c|c|}
\hline \multirow{2}{*}{ Pengetahuan } & \multicolumn{2}{|c|}{ PreTest } & \multicolumn{2}{c|}{ PostTest } \\
\cline { 2 - 5 } & $\mathrm{n}$ & $\%$ & $\mathrm{n}$ & $\%$ \\
\hline Baik & 3 & 10,0 & 17 & 56,7 \\
\hline Cukup & 2 & 6,7 & 10 & 33,3 \\
\hline Kurang & 25 & 83,3 & 3 & 10,0 \\
\hline Total & 30 & 100,0 & 30 & 100,0 \\
\hline
\end{tabular}

Berdasarkan pengetahuan sebelum pelaksanaan kelas ibu hamil sebagian besar kategori kurang 25 responden (83,3\%), sedangkan pengetahuan sesudah pelaksanaan kelas ibu hamil terjadi peningkatan dimana sebagian besar berada pada kategori baik 17 responden $(56,7 \%)$.

Hasil penelitian menunjukkan pengetahuan ibu hamil sebelum pelaksanaan kelas ibu hamil sebagian besar berada pada kategori kurang 25 responden $(83,3 \%)$, sedangkan katagori baik 3 responden $(10,0 \%)$, hal ini menunjukkan masih ada hal-hal yang belum ibu-ibu hamil pahami dan ketahui tentang persiapan persalinan.Tetapi setelah pelaksanaan kelas ibu hamil, pengetahuan ibu hamil meningkat menjadi sebagian besar katagori baik (56,7\%). Sedangkan sikap ibu hamil sebelum pelaksanaan kelas ibu hamil sebagian besar dalam katagori baik, tetapi lebih meningkat $30 \%$ dalam katagori baik setelah 
pelaksanaan kelas ibu hamil.

Hal ini sejalan dengan hasil penelitian[6], yang menunjukkan bahwa pengetahuan ibu tentang perencanaan persalinan dan pencegahan komplikasi lebih baik pada ibu hamil pada daerah dengan kelas ibu hamil daripada pengetahuan ibu hamil pada daerah tanpa kelas ibu hamil[6]. Dan hasil penelitian sebelumnya juga di Desa Kaliaman Kecamatan Kembang Kabupaten Jepara, menunjukkan ada hubungan yang bermakna antara tingkat pengetahuan ibu dengan persiapan persalinan[7].

Pengetahuan adalah hasil penginderaan manusia atau hasil tahu seseorang terhadap objek melalui indera yang dimilikinya (mata, hidung, telinga, dan sebagainya) dan dipengaruhi oleh intensitas perhatian dan persepsi terhadap objek. Pengetahuan merupakan domain yang sangat penting untuk terbentuknya tindakan seseorang (overttbehavior)[8]. Pengetahuan dapat diperoleh dari beberapa sumber antara lain media cetak, elektronik, keluarga, teman, dan lainlain[9].

Pengetahuan ibu hamil tentang pemeriksaan dan perawatan kehamilan meliputi pengetahuan ibu tentang pengertian kehamilan, tanda kehamilan, keluhan yang sering dialami ibu hamil, perubahan fisik ibu hamil, perubahan emosional ibu hamil, jadwal pemeriksaan kehamilan, pelayanan kesehatan pada ibu hamil, menjaga ibu hamil dan janin sehat, hal-hal yang harus dihindari oleh ibu selama hamil, mitos/tabu, dan persiapan menghadapi persalinan[1].

Tabel 2 Kategori Sikap Pre Test dan Post Test tentang persiapan persalinan

\begin{tabular}{|c|c|c|c|c|}
\hline \multirow{2}{*}{ Sikap } & \multicolumn{2}{|c|}{ PreTest } & \multicolumn{2}{c|}{ PostTest } \\
\cline { 2 - 5 } & $\mathrm{N}$ & $\%$ & $\mathrm{n}$ & $\%$ \\
\hline Baik & 18 & 60,0 & 27 & 90,0 \\
\hline Kurang & 12 & 40,0 & 3 & 10,0 \\
\hline Total & 30 & 100,0 & 30 & 100,0 \\
\hline
\end{tabular}

Berdasarkan sikap sebelum pelaksanaan kelas ibu hamil sebagian besar kategori baik 18 responden $(60,0 \%)$, tetapi terjadi peningkatan pada kategori baik 27 responden $(90,0 \%)$ setelah pelaksanaan kelas ibu hamil.

Hal ini sesuai dengan penelitian[10], yang menemukan bahwa pendidikan kesehatan melalui kelas ibu hamil efektif untuk meningkatkan sikap positif responden terhadap kesehatan ibu dan anak.

Berdasarkan pendapat[11], bahwa pengetahuan seseorang tentang suatu objek mengandung dua aspek yaitu aspek positif dan aspek negatif. Kedua aspek ini akan menentukan sikap seseorang, semakin banyak aspek positif dan objek yang diketahui, maka akan menimbulkan sikap semakin positif terhadap objek tertentu[11].

Sikap masih merupakan convertbehavior artinya masihmenjadi perilaku tertutup dan belum tentu terwujud dalam suatu tindakan (overtbehavior). Untuk mewujudkan sikap menjadi overtbehavior diperlukan faktor pendukung dan situasi yang memungkinkan seperti kesiapan ibu menghadapi persalinan [12].

\section{Analisis Bivariat}

Tabel 3 Perubahan Pengetahuan Pre Test dan Post Test

\begin{tabular}{|c|c|c|c|}
\hline Pengetahuan & Rerata (s.b) & Selisih (s.b) & P \\
\cline { 1 - 2 } Pre Test & $\begin{array}{c}39,83 \\
(15,61)\end{array}$ & 32,50 & \\
\cline { 1 - 2 } Post Test & $\begin{array}{c}72,33 \\
(15,07)\end{array}$ & $(17,45)$ & 0,000 \\
& & \\
\hline
\end{tabular}

Hasil uji statistik pengetahuan dengan menggunakan $\mathrm{t}$ berpasangan (paired $\mathrm{t}$-test), menunjukkan nilai rerata berdasarkan pelaksanaan kelas ibu hamil pretest adalah 39,83 dan setelah pelaksanaan kelas ibu hamil 72,33 (post test), adanya perbedaan yang bermakna $(\mathrm{p}=0,000<\alpha 0,05)$.

Tabel 4 Perubahan Sikap Pre Test dan Post Test

\begin{tabular}{|c|c|c|c|}
\hline Sikap & Rerata (s.b) & Selisih (s.b) & $\mathrm{P}$ \\
\hline Pre Test & $\begin{array}{l}50,53 \\
(2,88)\end{array}$ & \multirow{2}{*}{$21,50(7,84)$} & \multirow{2}{*}{0,001} \\
\hline Post Test & $\begin{array}{l}72,03 \\
(8,17) \\
\end{array}$ & & \\
\hline
\end{tabular}

Hasil uji statistik sikap dengan menggunakan $\mathrm{t}$ berpasangan (paired $t$-test), menunjukkan nilai rerata berdasarkan pelaksanaan kelas ibu hamil pre test adalah 50,53 dan setelah pelaksanaan kelas ibu hamil 72,03 (post test), adanya perbedaan yang bermakna $(\mathrm{p}=0,000<\alpha 0,05)$. 
Analisa data menunjukkan terjadinya peningkatan rata-rata (mean) pengetahuan dan sikap ibu hamil sebelum dan sesudah pelaksanaan kelas ibu hamil.

Dari hasil penelitian, menunjukkan nilai rerata berdasarkan pengaruh kelas ibu hamil terhadap pengetahuan tentang persiapan persalinan sebelum pelaksanaan kelas ibu hamil (pre test) adalah 39,83 dan setelah pelaksanaan kelas ibu hamil (post test) adalah 72,33, hasil uji statistik menunjukkan adanya perbedaan bermakna $(p=0,000<0,05)$ berarti ada pengaruh pelaksanaan kelas ibu hamil terhadap pengetahuan tentang persiapan persalinan di Desa Sesela Wilayah Kerja Puskesmas Gunung Sari Kabupaten Lombok Barat. Kemudian nilai rerata berdasarkan pengaruh kelas ibu hamil terhadap sikap tentang persiapan persalinan sebelum pelaksanaan kelas ibu hamil (pre test) adalah 50,53 dan setelah pelaksanaan kelas ibu hamil (post test) adalah 72,03, hasil uji statistik menunjukkan adanya perbedaan bermakna $(\mathrm{p}=0,000<0,05)$ berarti ada pengaruh pelaksanaan kelas ibu hamil terhadap sikap tentang persiapan persalinan di Desa Sesela Wilayah Kerja Puskesmas Gunung Sari Kabupaten Lombok Barat.

Berdasarkan[13], pemberian intervensi berupakelas lbu hamil mampu meningkatkan pengetahuan dansikap tentang kehamilan dan persalinan pada ibu hamil. Hal ini juga sejalan dengan penelitian yang dilakukan oleh[14], tentang pengaruh kelas ibu hamil terhadap peningkatan pengetahuan dan keterampilan ibu hamil mengenai kesehatan ibu dan anak di wilayah Puskesmas Sempor II Kabupaten Kebumen, bahwa ada perbedaan yang bermakna antara keterampilan sesudah dan satu bulan sesudah pelatihan kelas ibu hamil.

Pengetahuan merupakan salah satu pendorong seseorang untuk merubah perilaku atau mengadopsi perilaku baru[15]. Perubahan pengetahuan dan sikap dapat dilakukan dengan beberapa strategi salah satu strategi diantaranya dengan pemberian informasi untuk meningkatkan pengetahuan dan sikap seseorang sehingga menimbulkan kesadaran yang pada akhirnya orang itu akan memiliki sikap yang sesuai dengan pengetahuannya. Dalam hal ini, kelas ibu hamil merupakan salah satu upaya pemberian informasi melalui kelompok belajar dimana ibu-ibuhamil bisa belajar bersama, diskusi dan saling tukar pengalaman tentang kesehatan ibu dan anak secara menyeluruh dansistematis yang dilaksanakan secara terjadwal dan berkesinambungan[1].

Hal ini menunjukkan bahwa pelaksanaan kelas ibu hamil bermanfaat untuk ibu dalam persiapan persalinan oleh karena ibu hamil mendapatkan informasi kesehatan ibu dan anak, bertukar pendapat dan mendapat pengetahuan serta ketrampilan tentang persiapan persalinan[3].

\section{KESIMPULAN}

1. Pengetahuan ibu hamil sebelumpelaksanaan kelas ibu hamil tentang persiapan persalinan di Desa Sesela Wilayah Kerja Puskesmas Gunung Sari Kabupaten Lombok Barat sebagian besar berada pada kategori kurang dan mengalami peningkatan setelah pelaksanaan kelas ibu hamil dimana sebagian besar berada pada kategori baik.

2. Sikap ibu hamil sebelum pelaksanaan kelas ibu hamil tentang persiapan persalinan di Desa Sesela Wilayah Kerja

3. Puskesmas Gunung Sari Kabupaten Lombok Baratsebagian besar berada pada kategori baik dan mengalami peningkatan pada kategori baik 30\% setelah pelaksanaan kelas ibu hamil.

4. Ada pengaruh pelaksanaan kelas ibu hamil terhadap pengetahuan dan sikap tentang persiapan persalinan di Desa Sesela Wilayah Kerja Puskesmas Gunung Sari Kabupaten Lombok Barat.

\section{E. UCAPAN TERIMA KASIH}

Ucapan terima kasih penulis sampaikan kepada seluruh responden dan semua pihak yang telah mendukung dalam pelaksanaan dan penulisan penelitian ini. Ucapan terima kasih 
secara khusus Puskesmas tempat lokasi penelitian yang telah memberikan ijin penyelenggaraan penelitian ini.

\section{DAFTAR PUSTAKA}

[1]. Kemenkes RI. Pedoman Pelaksanaan Kelas Ibu Hamil. Kemenkes R. Jakarta, 2012.

[2]. SDKI. Survei Demografi dan Kesehatan Indonesia (SDKI). Jakarta: Badan Pusat Statistik., 2012.

[3]. Depkes RI. Pedoman Pelaksanaan Kelas Ibu Hamil. Kementrian. Jakarta, 2009.

[4]. Supartini T WN. Penerapan kelas Ibu terhadap Pengetahuan Ibu dan Frekuensi Antenatalcare.

[5]. Historyati D. Hubungan Pengetahuan dan Sikap Ibu Hamil Tentang Kelas Ibu Hamil dengan Partisipasi dalam Kelas Ibu Hamil Di wilayah Kerja Puskesmas Tembelang. UNS., 2003.

[6]. Romlah, S. . Pengaruh Kelas Ibu Hamil terhadap Perilaku Ibu dalam Merencanakan Persalinan dan Pencegahan Komplikasi di Kabupaten Garut Jawa Barat Tahun 2009, Tesis, Fakultas Kesehatan Masyarakat Universitas Indonesia. 2009.

[7]. Mochamad heri. HUBUNGAN KARAKTERISTIK DAN TINGKAT PENGETAHUAN IBU PRIMIGRAVIDA TRIMESTER III DENGAN PERSIAPAN MENGHADAPI PERSALINAN DI WILAYAH PUSKESMAS KECAMATAN KEMBANG KABUPATEN JEPARAhttp://digilib.unimus.ac.id/gdl.php ?mod=browse\&op=read\&id=jtptunimus- gdl-mochamadhe-5400 (2012).

[8]. Notoatmodjo. Ilmu Perilaku Kesehatan. Jakarta: Rineka Cipta, 2010.

[9]. Ariani PA. Aplikasi Metodologi Penelitian Kebidanan dan Kesehatan Reproduksi. Yogayakarta: Nuha Medika, 2014.

[10]. Hastuti, P.S., Nugroho, H.S., \& Usnawati N. Efektifitas Pelatihan Kelas Ibu Hamil untuk Meningkatkan Pengetahuan, Sikap, Keterampilan dan Kunjungan Antenatal Care. J Penelit Kesehat Suara Forikes,; II (2):122.

[11]. Wawan, A., dan Dewi M. Teori dan Pengukuran Pengetahuan, Sikap, dan Perilaku Manusia. CetakanII. Yogyakarta: Nuha Medika, 2011.

[12]. Maulana DJ. Promosi Kesehatan. Jakarta: EGC. Jakarta: EGC, 2010.

[13]. Dyah P. Pengaruh Kelas Ibu Hamil terhadap Pengetahuan dan Sikap Ibu dalam Kehamilan dan Persalinan di Wilayah Puskesmas Gurah Kabupaten Kediri, Surakarta. Universitas Sebelas Maret., 2012.

[14]. Linarsih. Pengaruh Kelas Ibu Hamil Terhadap Peningkatan Pengetahuan Dan keterampilan Ibu Hamil Mengenai Kesehatan Ibu Dan Anak Di Wilayah Puskesmas Sempor II Kabupaten Kebumen Tahun 2012. Jakarta : FKM UI., 2012.

[15]. Green, L.W., \& Kreuter MW (1991). Health Promotion Planing: An Educationaland Environmental Approach (Second Ed.). . Montain View,: Cal: Mayfield., 1991. 